\title{
Fine needle aspiration biopsy to reestablish cell culture in an animal model of uveal melanoma
}

\author{
Biópsia aspirativa com agulha fina para restabelecer cultura celular \\ em modelo animal de melanoma uveal
}

\author{
Zelia Maria da Silva Correa ${ }^{1}$ \\ Jean-Claude Marshall ${ }^{2}$ \\ João Pessoa Souza Filho ${ }^{3}$ \\ Alexandre Nakao Odashiro ${ }^{4}$ \\ Miguel Noel Burnier, Jr. ${ }^{5}$
}

\begin{abstract}
Purpose: To access the reliability of fine-needle aspiration biopsy in harvesting a sufficient amount of viable melanoma cells to establish a cell culture and maintain a melanoma cell line from an animal model of uveal melanoma. Methods: For this study, fifteen male New Zealand albino rabbits had their right eye surgically inoculated with uveal melanoma cell line 92.1. The animals were immunosupressed with cyclosporine A using a dose schedule previously published. The animals were followed for 12 weeks. Intraocular tumor growth was monitored weekly by indirect ophthalmoscopy. After the fourth week, one animal was sacrificed per week preceded by fine-needle aspiration biopsy using a sharp 25-gauge, 1 -inch long needle. Two separate aspirates were made from different areas of the tumor. Each aspirate was flushed to a separate cell culture media and sent for cell culture. The cells were frozen after two weeks when there were at least 1 million cells, which is enough to maintain a cell line. Cells were defrosted for HMB-45 immuno-stains to confirm the melanoma origin. Results: Cell growth was observed from the samples harvested from 11 out of the 15 animals inoculated with uveal melanoma. All cell cultures, after defrost, immunoassayed positive for HMB-45. Conclusion: Fine needle aspiration biopsy seems to be a reliable method to harvest cells from solid intraocular melanomas in an animal model, to establish cell culture and to maintain a melanoma cell line.
\end{abstract}

Keywords: Tumor cells; Animal model; Experimental models; Melanoma; Biopsy, needle; Cell culture

\section{INTRODUCTION}

According to a recent multicenter clinical trial, the ability of a specialtytrained Ocular Oncologist to diagnose uveal melanoma has increased from an average accuracy of $87.5 \%$ in 1980 to approximately $99.5 \%$ in $1990^{(1-2)}$. The increase in diagnostic accuracy reflects better clinician training and equipment; particularly the introduction of important non-invasive diagnostic tools such as A and B scan ultrasound. Advances have also been made in the local conservative treatment of the disease, specifically with plaque radiotherapy and transpupilary thermotherapy ${ }^{(3)}$. Regardless of the improvement in diagnosis and local treatment of uveal melanoma, the 10year mortality rate of approximately $50 \%$ remains almost the same as three decades ago ${ }^{(4)}$, and although the shift in treatment for uveal melanoma from enucleation to eye preserving methods has not impacted patient survival ${ }^{(5)}$, this change has implications for new experimental testing including gene 
chip arrays, cellular transfection and live cell imaging. These new techniques provide necessary tools to increase our understanding of the biological properties of uveal melanoma cells while allowing the investigation of processes such as cellular proliferation, gene activation, cell invasion, expression of soluble proteins, and metastatic behavior that could be individualized for each patient ${ }^{(6)}$. Consequently, the understanding of genetic expression profiling (GEP) of uveal melanoma is required to investigate future systemic therapies that hopefully inhibit the formation of metastasis ${ }^{(6)}$. Under these circumstances, the possibility of using fine-needle aspiration biopsy to harvest tumor cells for culture has been considered ${ }^{(7)}$.

Fine-needle aspiration biopsy (FNAB) consists of impaling a lesion with a small-caliber hollow-lumen needle and aspirating cells into the lumen of the needle to obtain minute fragments of a tumour ${ }^{(8)}$. FNAB has been extensively studied in Medicine ${ }^{(9)}$, however, its use in Ophthalmology has been limited to select intraocular lesions suspected of malignan$\mathrm{cy}^{(8,10)}$. The use of a fine-needle serves to avoid or minimize bleeding, intraoperative complications and potential tumor dissemination. However the small caliber is known to limit the amount of cells obtained ${ }^{(8)}$.

Over the past several decades, considerable effort has been directed towards developing a suitable animal model to study uveal melanoma. Although experimental models may never exactly replicate the disease in humans, a major advance has come from the use of human uveal melanoma cell lines capable of inducing tumor growth and metastatic disease in immunodefficient hosts ${ }^{(6,11)}$. Animal models that simulate disease progression may facilitate the development of methods for early detection and treatment of metastatic uveal melano$\mathrm{ma}^{(11)}$ as well as possible interventions such as fine-needle aspiration biopsy.

This study aimed to assess the reliability of fine-needle aspiration biopsy (FNAB) in harvesting a sufficient number of viable intraocular tumor cells from an animal model of uveal melanoma with the goal of reestablishing a cell culture and maintaining a melanoma cell line.

\section{METHODS}

The starting-point of this project was an animal model of uveal melanoma previously established by The Henry C. Witelson Ocular Pathology Laboratory, McGill University, Montreal, Canada ${ }^{(11-13)}$. The McGill University Institutional Review Board has approved this experiment and the animals were handled according to the ARVO Statement for the Use of Animals in Ophthalmic and Vision Research. The eyes of fifteen male, New Zealand albino rabbits were surgically inoculated with human uveal melanoma cell line 92.1 established by Dr. Jager (University Hospital Leiden, The Netherlands), using a previously described surgical procedure ${ }^{(12,14)}$.

The animals were immunosupressed with cyclosporine A (Sandimmune ${ }^{\circledR} 50 \mathrm{mg} / \mathrm{ml}$, Novartis Pharmaceuticals Canada
Inc., Dorval, Quebec, Canada) following a previously published dose schedule that improves survival rate and produces a high percentage of intraocular tumors, with subsequent development of metastatic disease ${ }^{(12)}$. All animals received the same dose of cyclosporine ( $15 \mathrm{mg} / \mathrm{kg} /$ day) for 3 days prior to surgery and during the first 4 weeks following surgery. After that, only $10 \mathrm{mg} / \mathrm{kg} /$ day were used for the remaining 8 weeks. Cyclosporine was always administered intramuscularly.

Intraocular tumor growth was monitored weekly by indirect ophthalmoscopy. After the fourth week, one rabbit per week was biopsied and then sacrificed ${ }^{(11-12)}$. FNAB was performed using a sharp 25-gauge, 1-inch long needle, B-D ${ }^{\circledR}$ Precision Glide ${ }^{\circledR}$ needle, Becton Dickinson \& CO, Franklin Lakes, NJ, USA; attached via flexible plastic tubing to a $10 \mathrm{ml}$ aspirating syringe ${ }^{(10)}$. The procedure was monitored under indirect ophthalmoscopy. The biopsy needle was passed approximately $2 \mathrm{~mm}$ from the limbus, through the conjunctiva, sclera, uvea and neuroepithelial layers of the pars plana and into the midvitreous. Once the tip of the needle was advanced into the lesion, an assistant started to aspirate the tumor cells. The plunger of the syringe was forcibly pulled and quickly released three times, allowing the suction force in the line to equilibrate. The needle was withdrawn slowly from the tumor and the eye along the direct line between the ocular wall puncture site and the site tumor puncture. Immediately following needle withdraw, light digital pressure was applied to the globe at the needle puncture site and maintained for approximately one minute to tentatively provide intraocular hemostasis ${ }^{(15)}$. Immediately after that, a second needle biopsy was performed via the same pars plana puncture site to allow sampling of a different region of the tumor ${ }^{(8,10)}$. Each aspirate was flushed into a separate flask with cell culture media and sent to the laboratory.

Following the final needle withdraw, the animal was sacrificed and necropsied.

The cells were cultured in RPMI-1640 medium (500 milliliters) (Invitrogen Life Technologies, Burlington, Ontario, Canada), supplemented with $5 \%$ by volume heat inactivated fetal bovine serum (FBS; Invitrogen), 1,250 micrograms of fungizone (Invitrogen), and 50,000 units of penicillin-streptomycin (Invitrogen). Cells were cultured as a monolayer in 6 well plates (Fisher Scientific, Whitby, Ontario, Canada) and observed by the same author (JCM) twice weekly when the media was changed. Cell cultures were analyzed for possible contamination by phase contrast microscopy. The cultures were grown to confluence for 2 weeks or when there was a minimum of 1 million cells, enough to maintain a cell line. After that, the cultured cells were passed by treatment with $0.05 \%$ trypsin in EDTA (Fisher) at $37^{\circ} \mathrm{C}^{(6,14)}$ and then washed in $7 \mathrm{ml}$ RPMI-1640 media before being centrifuged at $120 \mathrm{~g}$ for 8 minutes to form a pellet. The cells were then resuspended and stored in liquid nitrogen.

Finally, cells were thawed one month after the conclusion of the animal model study for HMB-45 immuno-stains to confirm that the cultured cells were actually of melanoma origin. Invasion assay using a modified Boyden chamber consisting 
of polyethylene teraphthalate membrane (PET) with 8- $\mu$ m diameter pores precoated with Matrigel, an artificial basement membrane, (Beckton Dickenson Labware, Bedford, MA, USA) was used as previously described ${ }^{(16)}$. And a proliferation colorimetric assay - the Sulforhodamine-B assay developed by the National Cancer Institute, specifically designed for the rapid and sensitive testing of potential anti-cancer agents, previously proven valuable to establish ranking and confirm the proliferation capabilities of uveal melanoma cells was used ${ }^{(14)}$. All of these assays were used to insure that the reestablished cell culture had similar characteristics as the original cell line inoculated in the animal model.

The results were analyzed and described by means of absolute numbers and percentages.

\section{RESULTS}

All fifteen animals were successfully inoculated with uveal melanoma cell line 92.1. Three animals died between the first and third weeks due to complications such as gastrointestinal hemorrhages, anorexia and diarrhea, all related to cyclosporine A toxicity. Twelve animals were subjected to FNAB. All animals presented some degree of intraocular hemorrhage after the first puncture but which did not prevent the second needle pass. Since the cells were flushed directly into culture media after the FNAB, it was not possible to determine the amount of cells harvested from each animal.

Cell growth was observed in the samples harvested from 11 out of the 12 animals biopsied (91.6\%). At the time of initial cell culture, each fine-needle biopsy resulted in the establishment of several foci of cell growth. Cellular morphology of the cultured fine-needle aspirates closely resembled that of the 92.1 cell line originally inoculated into the eyes of the rabbits. All cells were viable after thawing from storage in liquid nitrogen and immunoassayed positively for HMB-45. Invasion and proliferation assays were performed in all the reestablished cultures as mentioned in the previous session. All assays confirmed the presence of similar characteristics of the reestablished cell cultures and the uveal melanoma cell line 92.1.

The only eye from which FNAB did not establish a melanoma cell culture presented a flat, infiltrative lesion. The cell culture was initially misleading because of a cellularity observed during the first week that was due to blood cells and fibroblast proliferation. In all eleven cases, the amount of cells grown in culture after two weeks varied from 1 to 3.5 million cells. Cell cycle time (Tc) varied between 1.5 to 2 days.

\section{DISCUSSION}

FNAB has been extensively studied in both skin and uveal melanoma. It has also been investigated as an alternative method of fibroblast collection for culture with the purpose of future cytogenetic and metabolic studies ${ }^{(17)}$ and as a source of thyroid cells to test cyclin-dependent kinase inhibitor expression ${ }^{(18)}$.
Tumor-host interactions have traditionally been studied in excised surgical specimens by morphological or molecular methods to estimate protein or gene expression or to identify genetic abnormalities. However, these methods do not allow the assessment of functional interactions between various cell populations infiltrating these tumours ${ }^{(11)}$. On the other hand, the feasibility of tumor-infiltrating lymphocyte expansion from minimal FNAB material has been reported ${ }^{(19)}$. Although it is not clear whether cultured cells are representative of in vivo conditions, experiments performed with cell lines have established important principles of $\mathrm{T}$ cell-epitope interaction, which has allowed the formulation of useful hypotheses ${ }^{(19-20)}$.

Studies on skin melanoma lymph node metastasis have proved that FNAB is an efficient and effective method of tissue procurement, capable of generating sequentially and from the same lesion, fresh tumor cells, tumor infiltrating lymphocytes and long-term skin melanoma cell lines ${ }^{(20)}$.

The use of FNAB in selected human intraocular tumors including ocular melanomas has been reported ${ }^{(8,10)}$. This method has been mainly employed as a diagnostic tool for selected uveal melanomas while only one isolated publication reported the use of this technique for tissue culture ${ }^{(7)}$. However, in that study, FNAB was performed on a limited number of freshly enucleated globes unlike the study herein. The use of an animal model of uveal melanoma in this study was an attempt to simulate the clinical setting of FNAB performed in human eyes containing uveal melanoma prior to conservative treatment such as plaque radiotherapy. This model has the advantage of using human cells, allowing clinical monitoring of the tumor, and clinical correlation with human eyes, although an obvious disadvantage is the need of continuous immunosuppression of the rabbits ${ }^{(6,11)}$ that ultimately led to the death of three animals.

This study revealed effective cell cultures originated from FNAB harvested cells of most of the animals. Interestingly, the fundus examination of the only animal from which FNAB did not establish a cell culture, revealed an extensive retinal detachment overlying a diffuse choroidal thickening but no solid, elevated mass was detected. The fact that it is difficult to yield sufficient cells from small and rather flat choroidal melanomas has been reported in clinical studies ${ }^{(8,21)}$. Similarly, this limitation was also encountered in our animal model.

Proving the ability to establish a cell culture from FNAB harvested uveal melanoma cells of an animal model allows the investigation of future tests that can be performed in patients treated by conservative methods. A limited number of cells harvested from such tumors could be cultured and used for molecular testing, cytology, and immune assays, that could possibly provide an individualized prognosis as well as potential for response to tumor treatment. Since FNAB has proven to be effective in the majority of eyes in this animal model, this is theoretically possible, but future studies will be necessary to evaluate the value of routine application of this technique in humans.

In conclusion, fine-needle aspiration biopsy appears to be a reliable method of harvesting melanoma cells from primary 
intraocular tumors in an immunosuppressed animal model. It was shown that these cells could be re-cultured for use in potential in vitro assays.

\section{RESUMO}

Objetivo: Acessar a confiança da colheita de amostra celular suficiente através da biópsia aspirativa com agulha fina para estabelescer uma cultura celular e manter uma linhagem de células de melanoma a partir de uma modelo animal de melanoma uveal. Métodos: Para esse estudo, 15 coelhos albinos da Nova Zelândia foram inoculados cirurgicamente com a linhagem celular 92.1 de melanoma uveal. Os animais foram imunosuprimidos com ciclosporina A usando uma dose previamente publicada. Os animais foram acompanhados por 12 semanas. O crescimento de tumor intraocular foi monitorado semanalmente pela oftalmoscopia indireta. Após a quarta semana, um animal foi sacrificado por semana, precedido pela biópsia aspirativa com agulha fina usando uma agulha de gauge 25 e comprimento $2,5 \mathrm{~cm}$. Dois aspirados separados foram realizados a partir de áreas diferentes do tumor. Cada aspirado foi descarregado em um meio de cultura individual e enviado para cultura celular. As células foram congeladas após 2 semanas de cultura ou quando haviam pelo menos 1 milhão de células, o que é suficiente para manter uma linhagem celular. As células foram descongeladas para realizar imunocitoquímica com HMB-45 e confirmar sua origem melanocítica maligna. Resultados: Crescimento celular foi observado nas amostras colhidas em 11 dos 15 animais inoculados com melanoma uveal. Todas as culturas celulares, após serem descongeladas, apresentaram imunoexpressão positiva para o HMB-45. Conclusão: Biópsia aspirativa com agulha fina parece ser um método confiável para colher células de tumores oculares sólidos em um modelo animal visando estabelecer e manter essa linhagem celular de melanoma.

Descritores: Células tumorais; Modelo animal; Modelos experimentais; Melanoma; Biópsia por agulha; Cultura celular

\section{REFERENCES}

1. Chang M, Zimmerman LE, McLean I. The persisting pseudomelanoma problem. Arch Ophthalmol. 1984;102(5):726-7.
2. Accuracy of diagnosis of choroidal melanomas in the Collaborative Ocular Melanoma Study. COMS report $\mathrm{n}^{\circ}$ 1. Arch Ophthalmol. 1990;108(9):1268-73. Erratum in: Arch Ophthalmol. 1990;108(12):1708.

3. Harbour JW, Meredith TA, Thompson PA, Gordon ME. Transpupillary thermotherapy versus plaque radiotherapy for suspected choroidal melanomas. Ophthalmology. 2003;110(11):2207-14; discussion 2215.

4. Singh AD, Topham A. Survival rates with uveal melanoma in the United States: 1973-1997. Ophthalmology. 2003;110(5):962-5.

5. Augsburger JJ, Corrêa ZM, Freire J, Brady LW. Long-term survival in choroidal and ciliary body melanoma after enucleation versus plaque radiation therapy. Ophthalmology. 1998;105(9):1670-8.

6. Marshall JC, Caissie AL, Burnier MN Jr. How in vitro techniques have increased our understanding of uveal melanoma cellular biology. Can J Ophthalmol. 2004; 39(4):428-32.

7. Schachat AP, Newsome DA, Miller E, McDonnell PJ, Green WR, LaFrance N Tissue culture of human choroidal melanoma cells obtained by fine-needle aspiration biopsy. Graefes Arch Clin Exp Ophthalmol. 1986;224(5):407-13.

8. Augsburger JJ, Corrêa ZM, Schneider S, Yassin RS, Robinson-Smith T, Ehya $\mathrm{H}$, Trichopoulos N. Diagnostic transvitreal fine-needle aspiration biopsy of small melanocytic choroidal tumors in nevus versus melanoma category. Trans Am Ophthalmol Soc. 2002;100:225-32; discussion 232-4.

9. Frable WJ. Fine-needle aspiration biopsy: a review. Hum Pathol. 1983;14(1):9-28.

10. Augsburger JJ. Fine needle aspiration biopsy of suspected metastatic cancers to the posterior uvea. Trans Am Ophthalmol Soc. 1988;86:499-560.

11. Blanco PL, Caissie AL, Burnier MN Jr. Experimental models of uveal melanoma. Can J Ophthalmol. 2004;39(4):441-7.

12. Blanco G, Saornil AM, Domingo E, Diebold Y, López R, Rábano G, Tutor CJ. Uveal melanoma model with metastasis in rabbits: effects of different doses of cyclosporine A. Curr Eye Res. 2000;21(3):740-7.

13. De Waard-Siebinga I, Blom DJ, Griffioen M, Schrier PI, Hoogendoorn E, Beverstock G, et al. Establishment and characterization of an uveal-melanoma cell line. Int J Cancer. 1995;62(2):155-61.

14. Marshall JC, Caissie AL, Callejo SA, Antecka E, Burnier Jr MN. Cell proliferation profile of five human uveal melanoma cell lines of different metastatic potential. Pathobiology. 2004;71(5):241-5.

15. Corrêa ZMS, Irion LD, Augsburger JJ, Schneider S, Erwenne CM. Correlação entre a citologia e a histologia nas lesões intraoculares suspeitas de malignidade. Arq Bras Oftalmol. 2003;66(3):339-43.

16. Woodward JK, Elshaw SR, Murray AK, Nichols CE, Cross N, Laws D, et al. Stimulation and inhibition of uveal melanoma invasion by HGF, GRO, IL1alpha and TGF-beta. Invest Ophthalmol Vis Sci. 2002;43(10):3144-52.

17. Kurtycz DF, Logrono R, Harris C, Asplund S, O'Donnell L. Use of fine needle aspiration for fibroblast culture. Pediatr Pathol Lab Med. 1998;18(1):35-9.

18. Troncone G, Fulciniti F, Zeppa P, Vetrani A, Caleo A, Palombini L. Cyclindependent kinase inhibitor p27(Kip1) expression in thyroid cells obtained by fine-needle aspiration biopsy: a preliminary report. Diagn Cytopathol. 2000; 23(2):77-81.

19. Panelli MC, Riker A, Kammula U, Wang E, Lee KH, Rosenberg SA, Marincola FM. Expansion of tumor-T cell pairs from fine needle aspirates of melanoma metastases. J Immunol. 2000;164(1):495-504.

20. Riker AI, Panelli MC, Kammula US, Wang E, Wunderlich J, Abati A, et al Development and characterization of melanoma cell lines established by fineneedle aspiration biopsy: advances in the monitoring of patients with metastatic melanoma. Cancer Detect Prev. 1999;23(5):387-96.

21. Cohen VM, Dinakaran S, Parsons MA, Rennie IG. Transvitreal fine needle aspiration biopsy: the influence of intraocular lesion size on diagnostic biopsy result. Eye 2001;15(Pt 2):143-7. 